\title{
The Effect of Estrogen on Bone Marrow-Derived Rat Mesenchymal Stem Cell Maintenance: Inhibiting Apoptosis Through the Expression of $\mathrm{Bcl}-\mathrm{x}_{\mathrm{L}}$ and Bcl-2
}

\author{
Fatma Ayaloglu-Butun • Ece Terzioglu-Kara • \\ Zeynep Tokcaer-Keskin • Kamil Can Akcali
}

Published online: 28 June 2011

(C) Springer Science+Business Media, LLC 2011

\begin{abstract}
Mesenchymal Stem Cells (MSCs) have high therapeutic value for regenerative medicine and tissue engineering due to their differentiation potential and nonimmunogenic characteristics. They are also considered as an effective in vivo delivery agent because of their ability to migrate to the site of injury. A major roadblock in their use for cell-based therapies is their rareness in vivo. Therefore, it is important to obtain increased number of functional MSCs in vitro in order to have adequate numbers for therapeutic regiments. We aimed to investigate the role of estrogen and its mechanism in obtaining more MSCs. MSCs were isolated from female and ovariectomized rats and cultured in the presence and absence of $10^{-7} \mathrm{M}$ estrogen. In the presence of estrogen, not only their CFU$\mathrm{F}$ activity increased but also apoptotic rate decreased as shown by TUNEL staining leading to obtain more MSCs. Also the number of the cells in the colonies increased upon estrogen treatment. To reveal the mechanism of this effect, we focused on Bcl-2 family of proteins. Our immunoblotting experiments combined with knockdown studies suggested a critical role for anti-apoptotic Bcl- $\mathrm{x}_{\mathrm{L}}$ and Bcl-2. Estrogen treatment up regulated the expression $\mathrm{Bcl}-\mathrm{x}_{\mathrm{L}}$ and Bcl-2. When we knocked down the expression of $b c l-x_{L}$ and $b c l-2$, MSCs lacking these genes showed an increase in the apoptotic rate in contrast to normal MSCs following estrogen treatment. Therefore, estrogen treatment will be of great advantage for cell-based therapies in order to get more functional MSCs and may provide opportunities to develop new strategies for debilitating diseases.
\end{abstract}

F. Ayaloglu-Butun • E. Terzioglu-Kara • Z. Tokcaer-Keskin •

K. C. Akcali $(\bowtie)$

Department of Molecular Biology and Genetics,

Bilkent University,

Ankara, Turkey 06800

e-mail: akcali@fen.bilkent.edu.tr
Keywords Mesenchymal stem cells · Estrogen · Apoptosis · $\mathrm{Bcl}-2 \cdot \mathrm{Bcl}-\mathrm{x}_{\mathrm{L}} \cdot$ Rat $\cdot$ Tunel

\section{Introduction}

Increased human lifespan has brought the concept of a better life quality, since the body functions and health conditions decline with time. Identifying with the pioneering studies of Friedenstein [1], mesenchymal stem cells (MSCs) have demonstrated great potential to tackle these problems. Multipotent MSCs have potential to differentiate into tissue-specific cell types such as osteocytes, adipocytes, chondrocytes, myoblasts, cardiomyocytes [1-3]. MSCs emerge as an important player of cellular-based therapies in wide variety of pathologies such as neurodegenerative and cardiovascular diseases, diabetes, and cancer due to their ability to migrate in vivo to promote regeneration of damaged tissue, treat inflammation, and promote angiogenesis without inducing immune reaction [4-7]. Besides being a future promise for many disease treatments, there are also some handicaps in their applications. One major roadblock is their rareness and the fact that they constitute a very small population of nucleated cells in the bone marrow [8]. Their number has to be increased before they can be used for therapeutic purposes.

Similar to stem cells, estrogen hormone can also be accepted as a key factor in the preservation of life standards. Estrogen is mainly responsible for female sexual features but also influences many physiological processes in mammals including cellular proliferation and apoptosis $[9,10]$. In humans, increased incidence of osteoporosis and coronary heart diseases after menopause suggests the involvement of estrogen in these disorders [11, 12]. Since MSCs differentiate into bone and muscle cells, the effect of 
estrogen on MSCs is also critical. Understanding the mechanism of their interaction is vital for obtaining the maximum efficiency from this collaboration. Apoptotic pathways, which are conserved throughout evolution, are strong candidates for this cooperation. Estrogen has a dual role on apoptosis; it can both stimulate and inhibit apoptosis depending on the type of cell, the duration and amount of estrogen and the downstream target signaling pathway. Estrogen promotes apoptosis in osteoclasts, thymocytes and neurons [13-16]. On the other hand, it has antiapoptotic effect on osteocyte, umbilical vein endothelial cells, hippocampal neurons and breast cancer cell lines [17-20].

Although the mechanism of the apoptotic or antiapoptotic function of estrogen is not always through the same pathway, regulation through the $b c l-2$ family of genes is a major candidate in this process. The members of the Bcl-2 family of proteins determine the life-or-death of a cell by controlling the release of mitochondrial apoptogenic factors, cytochrome c and apoptosis inducing factors (AIF), which activate the downstream executional phases, including the activation of the caspases [21, 22]. Estrogen increases the expression of anti-apoptotic but decreases the expression of pro-apoptotic $b c l-2$ family of genes [19, $23,24]$. The effect of estrogen on the expression of $b c l-x_{L}$ and $b c l-2$ is mediated through estrogen response element (ERE) sites of these genes [19, 23]. In addition, estrogen can also affect the expression of Bcl-2 family of genes through the non genomic pathway which involves the phosphorylation of the proteins [24]. Regardless of the mechanism, it is evident that estrogen has a crucial role in apoptotic regulation.

The present study was undertaken to investigate the molecular mechanisms of estrogen during MSC maintenance. In order to explain the mechanism of the action of estrogen, we hypothesize that estrogen differentially regulates the expression of $b c l-2$ family of genes and this control results in obtaining more MSC by inhibiting apoptosis.

\section{Material and Methods}

\section{Isolation and Culture of MSCs}

MSCs were obtained from female and ovariectomized female 9-week old, 280-300 g Sprague-Dawley rats. The animals were permitted unlimited access to food and water at all times and were housed under controlled environmental conditions $\left(22^{\circ} \mathrm{C}\right)$ with a 12-hour light and $12 \mathrm{~h}$ dark cycle in the animal holding facility of the Department of Molecular Biology and Genetics at the Bilkent University. This study protocol complied with Bilkent University's guidelines on humane care and use of laboratory animals. Bone marrow heterogeneous cell population was collected from the femur and tibia by flushing with a $5 \mathrm{~mL}$ syringe containing 10\% FBS (Hyclone, Logan, UT, USA) in DMEM (Invitrogen, Paisley, UK) after the rats were sacrificed by cervical dislocation. The cells were cultured in plastic culture dishes with Mesencult Media (StemCell Technology, Vancouver, Canada) with $20 \%$ supplement (StemCell Technology) and a 1\% penicillin/streptomycin solution (Hyclone) in a $5 \% \mathrm{CO}_{2}$ incubator at $37^{\circ} \mathrm{C}$. The next day, the media of the tissue culture plates were changed and the non-adherent cells were removed. The media of the cells were changed every 4 days, after washing with sterile 1x PBS prior to the change. For the estrogen treatment, MSCs were cultured with $10^{-7} \mathrm{M}$ estrogen (17 Bestradiol, Sigma, MO, USA).

\section{Colony-Forming Assay}

After washed in 1x PBS and air dried, MSCs were fixed with cold methanol for $5 \mathrm{~min}$. The cells were washed again in a 1x PBS buffer and stained with giemsa (Carlo Erba, Milano, Italy) for $5 \mathrm{~min}$. The reaction of the giemsa staining was stopped by the addition of tap water. The number of colonies was counted under light microscope.

\section{In Situ Analysis of DNA Fragmentation (TUNEL)}

DNA fragmentation was detected in situ by TdT- (terminal deoxynucleotidyl transferase) mediated fluorescein-dUTP labeling kit (Roche Diagnostics, Mannheim, Germany). Cells were fixed in $4 \%$ paraformaldehyde in PBS for $20 \mathrm{~min}$ at room temperature and then washed in PBS for $30 \mathrm{~min}$. After incubating with a permeabilisation solution $(0.1 \%$ Triton X-100, $0.1 \%$ sodium citrate) for $2 \mathrm{~min}$ on ice, $50 \mu \mathrm{l}$ of TUNEL reaction mixture was put into each sample and incubated for $1 \mathrm{~h}$ at $37^{\circ} \mathrm{C}$ in the dark in a humidified chamber. Slides were then directly analyzed by fluorescence microscopy. For evaluation by fluorescence microscopy, we used an excitation wavelength in the range of $450-500 \mathrm{~nm}$ and detection in the range of $515-565 \mathrm{~nm}$. As negative control, we incubated the samples in the absence of terminal deoxynucleotidyl transferase. For positive controls, the samples were first treated with DNase I $(1,000 \mathrm{U} / \mathrm{ml}$ in $50 \mathrm{mM}$ Tris-HCl, $\mathrm{pH} 7.5,1 \mathrm{mg} / \mathrm{ml} \mathrm{BSA})$ for $10 \mathrm{~min}$ at $20^{\circ} \mathrm{C}$ to induce DNA strand breaks prior to labeling procedures and then incubated with $50 \mu$ l of TUNEL reaction mixture.

Total RNA Isolation and Reverse Transcription

MSCs were trypsinized and the total cellular RNA was isolated from the precipitate by using the RNeasy Mini kit 
(Qiagen, Hilden, Germany) according to the manufacturer's protocol, with additional DNase treatment. The cDNAs were synthesized from the total RNA samples with the DyNAmo cDNA synthesis kit (Finnzymes, Espoo, Finland) according to the manufacturer's protocol.

\section{RT-PCR}

cDNA amplification for $b c l 2, b c l-x_{L}, C D 90, C D 71, C D 45$, $C D 34, C D 29, M M P 12, G A P D H$, and $\beta$-Actin were performed by using DyNAzyme II (Finnzymes). The primers and conditions of amplification indicated in Table 1 and 2 respectively.

Protein Isolation and Quantification

MSCs were scraped from the cell culture plates in 1x PBS and the precipitate was treated with a lysis buffer containing $0.05 \mathrm{M}$ Tris $\mathrm{HCl}$, 1x protease inhibitor, $0.25 \mathrm{M} \mathrm{NaCl}$ and $1 \%(v / v)$ IGEPAL for $30 \mathrm{~min}$ on ice. Then the lysate was centrifugated for $20 \mathrm{~min}$ at $13,000 \mathrm{rpm}$ and $4^{\circ} \mathrm{C}$. Protein concentrations of supernatants were determined with Bradford protein assay as described [25].

\section{Western Blotting}

The proteins were separated on 10\% SDS-PAGE and transferred to a polyvinylidene fluoride membrane. The membrane was blocked with blocking solution for $2 \mathrm{~h}$ at room temperature and was incubated in antibody solution at the concentration of 1:500 (for Bcl- $x_{L}, B a k, B c l-2, B a x$ ); 1:200 (for $\mathrm{ER} \alpha, \mathrm{ER} \beta$ ) and 1:1000 for Actin for o/n at $4{ }^{\circ} \mathrm{C}$. Then the secondary antibody, anti-Rabbit-HRP were applied for $1 \mathrm{~h}$ in blocking solution at a concentration of 1:1000. Finally, Super Signal West Femto Maximum Sensitivity Substrate (Thermo Scientific, IL, USA) was applied to the membrane for $4 \mathrm{~min}$ and placed in an X-ray film cassette and developed. All antibodies, except for antiRabbit-HRP, were purchased from Santa Cruz (Santa Cruz, CA, USA).

Transfection of $b c l-2$ and $b c l-x_{L}$ shRNA

shRNA of $b c l-2$ and $b c l-x_{L}$ were purchased from Openbiosystems, (AL,USA) and prepared according to the manufacturer's protocol. $1 \mu \mathrm{g}$ Bcl-2 and Bcl- $\mathrm{x}_{\mathrm{L}}$ shRNA was added to $100 \mu \mathrm{L}$ serum free, antibiotic free DMEM-LG (HyClone). In another tube $4 \mu \mathrm{L}$ and $3 \mu \mathrm{L}$ transfection reagent Dharmafect (Thermo Scientific) was diluted with $196 \mu \mathrm{L}$ and $197 \mu \mathrm{L}$ serum free antibiotic free DMEM-LG for Bcl-2 and Bcl- $\mathrm{x}_{\mathrm{L}}$ respectively. After $5 \mathrm{~min}$ of incubation, the contents of shRNA and transfection reagent containing tubes were mixed and incubated at room temperature for $20 \mathrm{~min}$. 1,200 $\mu \mathrm{L}$ antibiotic free complete DMEM-LG was added to the mixture. The cells were washed with 1x PBS and then the transfection mixture was added. DMEM-LG and transfection reagent only was given to the cells as two types of control. Next day the medium

Table 1 Primers and the product size of the genes

\begin{tabular}{|c|c|c|c|}
\hline \multirow{2}{*}{ gapdh } & forward & 5'-CCTCCTCATTGACCTCAACTAC -3' & $210 \mathrm{bp}$ \\
\hline & reverse & 5'-CATGGTGGTGAAGACGCCAG-3' & \\
\hline \multirow[t]{2}{*}{ bcl-2 } & forward & 5'-CCTGGCATCTTCTCCTTC-3' & $584 \mathrm{bp}$ \\
\hline & reverse & 5'-TGCTGACCTCACTTGTGG-3' & \\
\hline \multirow[t]{2}{*}{$\mathrm{bcl}-\mathrm{x}_{\mathrm{L}}$} & forward & 5'-TCAATGGCAACCCTTCCTGG-3' & $346 \mathrm{bp}$ \\
\hline & reverse & 5'-ATCCGACTCACCAATACCTG-3' & \\
\hline \multirow[t]{2}{*}{ beta actin } & forward & 5'-CTGGCCTCACTGTCCACCTT- 3' & $65 \mathrm{bp}$ \\
\hline & reverse & 5'-GGGCCGGACTCATCGTACT- 3' & \\
\hline \multirow[t]{2}{*}{$\mathrm{CD} 90$} & forward & 5'- CCAGTCATCAGCATCACTCT- 3' & $374 \mathrm{bp}$ \\
\hline & reverse & 5'- AGCTTGTCTCTGATCACATT- 3' & \\
\hline \multirow[t]{2}{*}{ CD 34} & forward & 5'- TGTCTGCTCCTTGAATCT -3' & $281 \mathrm{bp}$ \\
\hline & reverse & 5'- CCTGTGGGACTCCAACT- 3' & \\
\hline \multirow[t]{2}{*}{ CD 71} & forward & 5'- ATGGTTCGTACAGCAGCAGA- 3' & $182 \mathrm{bp}$ \\
\hline & reverse & 5'- CGAGCAGAATACAGCCATTG- 3' & \\
\hline \multirow[t]{2}{*}{ CD 29} & forward & 5'-ACTTCAGACTTCCGCATTGG -3' & $190 \mathrm{bp}$ \\
\hline & reverse & 5'- GCTGCTGACCAACAAGTTCA- 3' & \\
\hline \multirow[t]{2}{*}{$\mathrm{CD} 45$} & forward & 5'- ATGTTATTGGGAGGGTGCAA-3' & $175 \mathrm{bp}$ \\
\hline & reverse & 5'- AAAATGTAACGCGCTTCAGG-3' & \\
\hline \multirow[t]{2}{*}{ Mmp 12} & forward & 5'- GGCAACTGGACACCTCAACT -3' & $382 \mathrm{bp}$ \\
\hline & reverse & 5'- GTCCAGGTTTCTGCCTCATC -3' & \\
\hline
\end{tabular}


Table 2 PCR conditions for the genes

\begin{tabular}{|c|c|c|c|c|c|c|}
\hline Genes & Initial denaturation & Denaturation & Annealing & Extension & Cycles & Final extension \\
\hline gapdh & $95^{\circ} \mathrm{C}, 5 \mathrm{~min}$ & $94^{\circ} \mathrm{C} 45 \mathrm{sec}$ & $\begin{array}{l}55^{\circ} \mathrm{C} \\
40 \mathrm{sec}\end{array}$ & $\begin{array}{l}72^{\circ} \mathrm{C} \\
40 \mathrm{sec}\end{array}$ & 23 & $72^{\circ} \mathrm{C}, 5 \mathrm{~min}$ \\
\hline bcl-2 & $95^{\circ} \mathrm{C}, 5 \mathrm{~min}$ & $94^{\circ} \mathrm{C} 40 \mathrm{sec}$ & $\begin{array}{l}63^{\circ} \mathrm{C} \\
35 \mathrm{sec}\end{array}$ & $\begin{array}{l}72^{\circ} \mathrm{C} \\
40 \mathrm{sec}\end{array}$ & 36 & $72^{\circ} \mathrm{C}, 5 \mathrm{~min}$ \\
\hline bcl- $x_{L}$ & $95^{\circ} \mathrm{C}, 5 \mathrm{~min}$ & $94^{\circ} \mathrm{C} 30 \mathrm{sec}$ & $\begin{array}{l}52^{\circ} \mathrm{C} \\
30 \mathrm{sec}\end{array}$ & $\begin{array}{l}72^{\circ} \mathrm{C} \\
30 \mathrm{sec}\end{array}$ & 31 & $72^{\circ} \mathrm{C}, 5 \mathrm{~min}$ \\
\hline beta actin & $95^{\circ} \mathrm{C}, 5 \mathrm{~min}$ & $94^{\circ} \mathrm{C} 40 \mathrm{sec}$ & $\begin{array}{l}60^{\circ} \mathrm{C} \\
35 \mathrm{sec}\end{array}$ & $\begin{array}{l}72^{\circ} \mathrm{C} \\
40 \mathrm{sec}\end{array}$ & 25 & $72^{\circ} \mathrm{C}, 5 \mathrm{~min}$ \\
\hline CD 90 & $95^{\circ} \mathrm{C}, 5 \mathrm{~min}$ & $94^{\circ} \mathrm{C} 30 \mathrm{sec}$ & $\begin{array}{l}55^{\circ} \mathrm{C} \\
30 \mathrm{sec}\end{array}$ & $\begin{array}{l}72^{\circ} \mathrm{C} \\
30 \mathrm{sec}\end{array}$ & 30 & $72^{\circ} \mathrm{C}, 5 \mathrm{~min}$ \\
\hline CD 34 & $95^{\circ} \mathrm{C}, 5 \mathrm{~min}$ & $94^{\circ} \mathrm{C} 30 \mathrm{sec}$ & $\begin{array}{l}55^{\circ} \mathrm{C} \\
30 \mathrm{sec}\end{array}$ & $\begin{array}{l}72^{\circ} \mathrm{C} \\
30 \mathrm{sec}\end{array}$ & 30 & $72^{\circ} \mathrm{C}, 5 \mathrm{~min}$ \\
\hline CD 71 & $95^{\circ} \mathrm{C}, 5 \mathrm{~min}$ & $94^{\circ} \mathrm{C} 40 \mathrm{sec}$ & $\begin{array}{l}66^{\circ} \mathrm{C} \\
60 \mathrm{sec}\end{array}$ & $\begin{array}{l}72^{\circ} \mathrm{C} \\
40 \mathrm{sec}\end{array}$ & 35 & $72^{\circ} \mathrm{C}, 5 \mathrm{~min}$ \\
\hline CD 29 & $95^{\circ} \mathrm{C}, 5 \mathrm{~min}$ & $94^{\circ} \mathrm{C} 30 \mathrm{sec}$ & $\begin{array}{l}60^{\circ} \mathrm{C} \\
30 \mathrm{sec}\end{array}$ & $\begin{array}{l}72^{\circ} \mathrm{C} \\
30 \mathrm{sec}\end{array}$ & 29 & $72^{\circ} \mathrm{C}, 5 \mathrm{~min}$ \\
\hline $\mathrm{CD} 45$ & $95^{\circ} \mathrm{C}, 5 \mathrm{~min}$ & $94^{\circ} \mathrm{C} 30 \mathrm{sec}$ & $\begin{array}{l}60^{\circ} \mathrm{C} \\
30 \mathrm{sec}\end{array}$ & $\begin{array}{l}72^{\circ} \mathrm{C} \\
30 \mathrm{sec}\end{array}$ & 23 & $72^{\circ} \mathrm{C}, 5 \mathrm{~min}$ \\
\hline Mmp 12 & $95^{\circ} \mathrm{C}, 10 \mathrm{~min}$ & $94^{\circ} \mathrm{C} 40 \mathrm{sec}$ & $\begin{array}{l}48^{\circ} \mathrm{C} \\
\quad 60 \mathrm{sec}\end{array}$ & $\begin{array}{l}72^{\circ} \mathrm{C} \\
40 \mathrm{sec}\end{array}$ & 28 & $72^{\circ} \mathrm{C}, 5 \mathrm{~min}$ \\
\hline
\end{tabular}

was changed to their normal media. 4 days after transfection, RNA isolation and TUNEL assays were performed.

\section{Adipogenic Differentiation}

An adipogenic induction medium was prepared freshly by adding $1 \mu \mathrm{M}$ dexamethasone (Sigma), $10 \mu \mathrm{g} / \mathrm{ml}$ insulin (Sigma), $100 \mu \mathrm{M}$ indomethacin (Sigma) and $0.5 \mathrm{mM}$ IBMX to LG-DMEM (HyClone), containing 1x penicillinstreptomycin (HyClone) and 10\% FBS (HyClone). The MSCs were cultured for 21 days, changing the medium every 2 days with freshly prepared medium. After 21 days the cells were fixed with $4 \%$ paraformaldehyde and stained with Oil Red O (Sigma).

\section{Osteogenic Differentiation}

An osteogenic induction medium was prepared by freshly adding $0.1 \mu \mathrm{M}$ dexamethasone (Sigma), $0.2 \mathrm{mM}$ ascorbic acid 2-phosphate (Sigma) and $10 \mathrm{mM}$ glycerol-2-phosphate (Sigma) to LG-DMEM (HyClone), containing $1 \mathrm{x}$ penicillin-streptomycin (HyClone) and 10\% FBS (HyClone). The MSCs were cultured for 21 days, changing the medium every 2 days with freshly prepared medium. After 21 days the cells were fixed with $10 \%$ formaldehyde and stained with Von Kossa (Sigma).

\section{Statistical Analysis}

All data are expressed as means \pm SD. Data were analyzed by performing paired $t$-test using Minitab Statistical
Software ${ }^{\circledR}$ (State College, Pennsylvania, USA). A value of $P<0.05$ was considered to be statistically significant.

\section{Results}

We first examined the characteristics of MSCs isolated from normal and ovariectomized rats and cultured in the absence or presence of $10^{-7} \mathrm{M}$ estrogen (Fig. 1). We repeated our experiments three times with three animals per group. By using RT-PCR, we showed that all of the experimental groups were positive for mesenchymal stem cell markers (CD29, CD71 and CD90) and negative for hematopoietic cell markers (CD34, CD45) (Fig. 1a). We also examined the expression levels of ER $\alpha$ and ER $\beta$ in our experimental groups. Our western blot data showed that both ER $\alpha$ and ER $\beta$ were expressed in MSCs isolated from normal and ovariectomized rats (Fig. 1b). We also showed that upon estrogen addition, the expression of an estrogen responsive gene, MMP12 increased both in normal and ovariectomized animals (Fig. 1c).

We then investigated the effect of estrogen treatment on MSCs' CFU-F activities and differentiation capabilities (Fig. 2). The results of our CFU-F assay showed that estrogen treatment caused an increase in the colony numbers of MSCs that were isolated from both normal and ovariectomized rats (Fig. 2a). Moreover, the number of the cells in the colonies also increased when MSCs were treated with estrogen (Fig. 2a). When MSCs isolated from both normal and ovariectomized animals were put into adipogenic and osteogenic differentiation medium, they 
A)
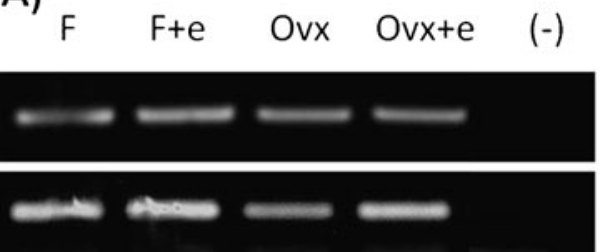

CD29

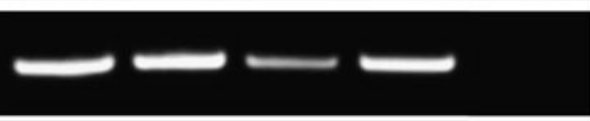

CD71

CD90

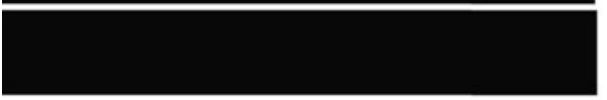

CD34

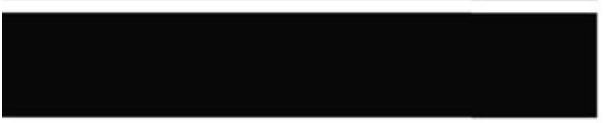

CD45

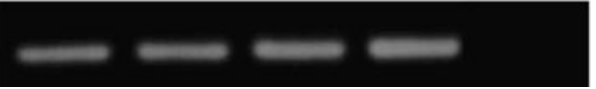

Actin

Fig. 1 Characterization of bone marrow-derived mesenchymal stem cells. a The expression of the markers of MSCs (CD90, CD29 and CD71) and hematopoietic cells (CD34, CD45) by RT-PCR. b Protein expression of $\mathrm{ER} \alpha$ and $\mathrm{ER} \beta$ determined by Western blot. Actin expression was used as loading control. $\mathbf{c}$ mRNA expression estrogen

were able to form adipocytes and osteocytes (Fig. 2b). Our results revealed that the capacity of differentiation into adipocyte lineage was to a lesser degree when MSCs were incubated in the presence of estrogen (Fig. 2b (ii vs $i v)$ ).
B)

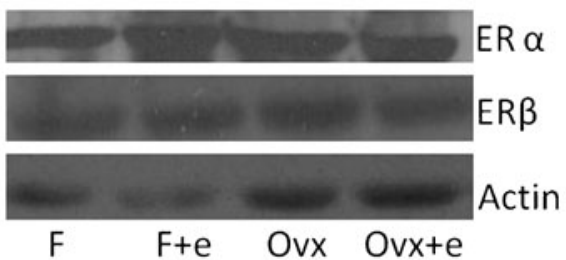

C)

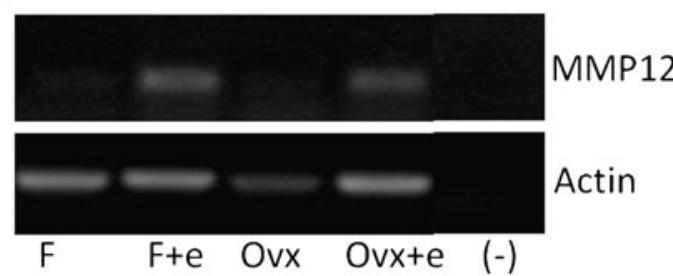

regulatory gene, MMP12 determined by RT-PCR. Actin expression was used as loading control. (F: MSCs obtained from female rats; F $+\mathrm{e}$ : MSCs obtained from female rats treated with estrogen; Ovx: MSCs obtained from ovariectomized rats; $\mathrm{Ovx}+\mathrm{e}$ : MSCs obtained from ovariectomized rats treated with estrogen.)

Since the cell number may be directly related to the involvement of apoptosis, we then examined the effect of estrogen on the apoptotic rate of MSCs (Fig. 3). Apoptotic rate was calculated as the ratio of TUNEL $(+)$ cells to the

\section{A)}
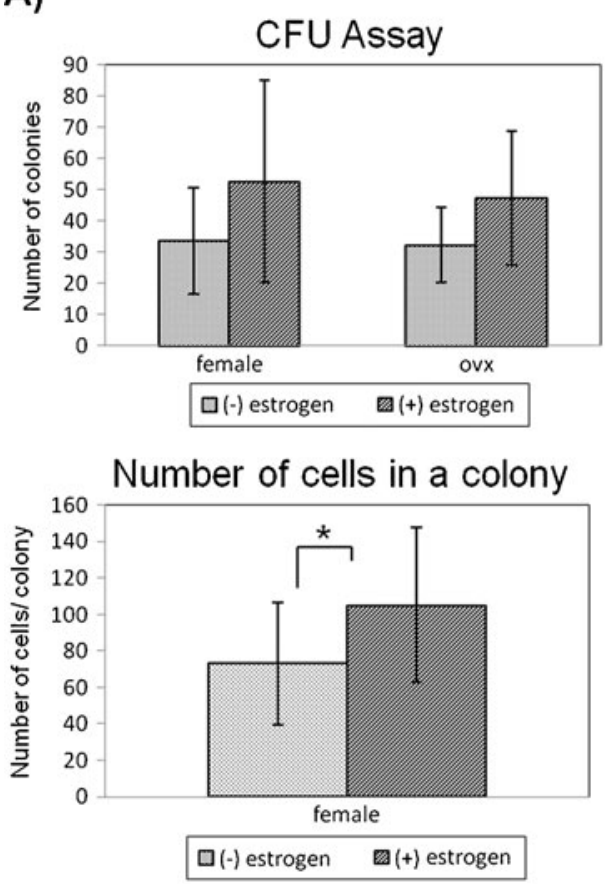

B) w/o estrogen
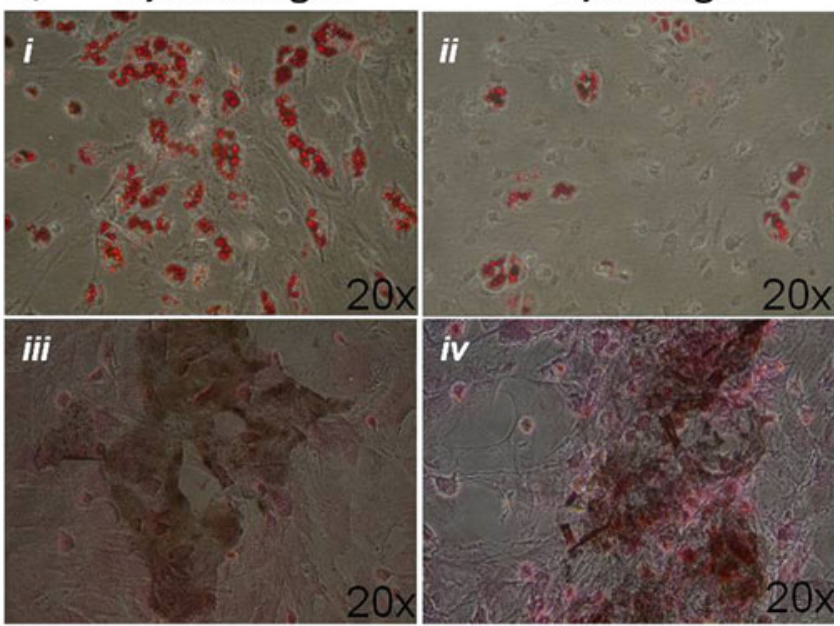

$v$

vi
Fig. 2 Effect of estrogen on the bone marrow-derived mesenchymal stem cells. a CFU activities and the number of the cells in a colony * indicates $p \leq 0.05$; $\mathbf{b}$ Differentiation capacities of MSCs in the absence (i, iii) and presence (ii, iv) of estrogen. MSCs were stained with Oil Red $\mathrm{O}$ to determine adipogenic differentiation $(i, i i)$, with Von Kossa staining to determine osteogenic differentiation (iii, iv) 

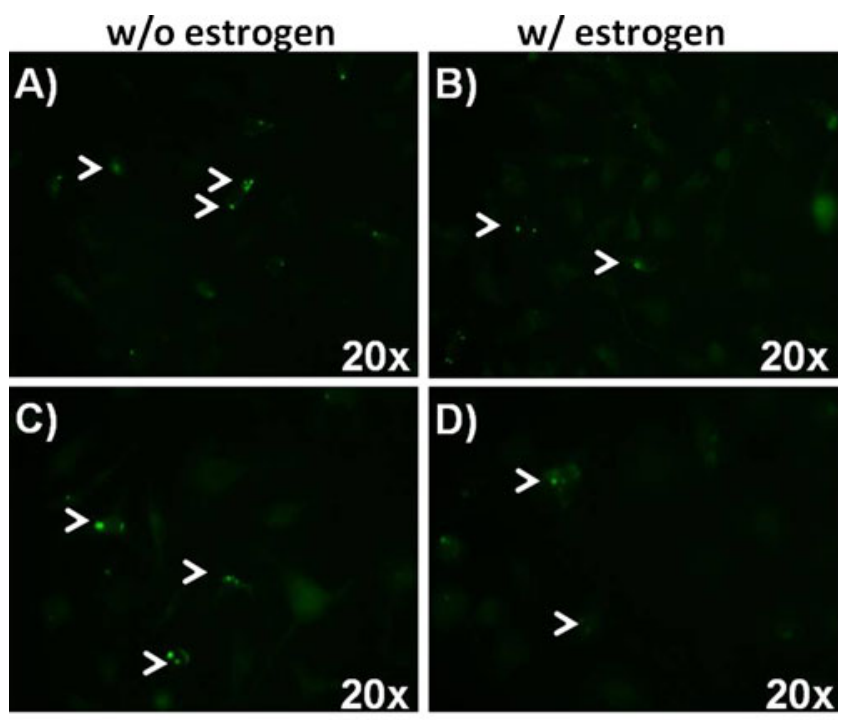

E)

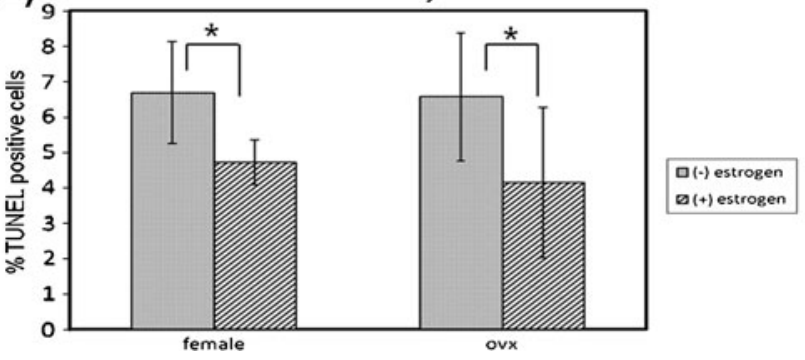

Fig. 3 In situ analysis of DNA fragmentation (TUNEL) of MSCs. MSCs were isolated from normal $(\mathbf{a}, \mathbf{b})$ and ovariectomized $(\mathbf{c}, \mathbf{d})$ rats. Cells were cultured in the absence $(\mathbf{a}, \mathbf{c})$ and presence $(\mathbf{b}, \mathbf{d})$ of estrogen. e Percentage of apoptotic cells. * indicates $p \leq 0.05$

total number of cells. Addition of estrogen decreased the number of TUNEL (+) MSCs isolated both from normal (Fig. 3a and b) and ovariectomized rats (Fig. 3c and d). Our results suggested that estrogen protects MSCs from apoptosis (Fig. 3e).

In order to understand the molecular mechanism of estrogen action on apoptosis, we focused on Bcl-2 family of proteins. We examined the expressions of both antiapoptotic (Bcl- $\left.\mathrm{x}_{\mathrm{L}}, \mathrm{Bcl}-2\right)$ and pro-apoptotic (Bak and Bax) members of this family (Fig. 4). Our western blot experiments revealed that addition of estrogen caused an increase in the expression of anti-apoptotic members of Bcl-2 family of proteins (Fig. 4a). On the other hand, we did not observe any change in the expression of pro-apoptotic members (Fig. 4b). We knocked down the expression of $b c l-2$ and $b c l-x_{L}$ by using shRNA to reveal that the anti-apoptotic effect of estrogen on MSCs was through these genes (Fig. 5a) and checked the effect of this silencing on the apoptotic rates of MSCs determined by TUNEL assay (Fig. 5b,c). Our results showed that the decreasing effect of estrogen on apoptosis in non-transfected MSCs reversed after transfecting the cells with shRNA of either $b c l$-2or $b c l-x_{L}$. The percentage of the apoptotic cells increased when $b c l-x_{L}$ or $b c l-2$ shRNA transfected cells cultured even in the presence of estrogen (Fig. $5 \mathrm{~b}$ and c respectively).

\section{Discussion}

Stem cells are the new hope for the humans since they have the potential to differentiate to several types of cells and tissues. They are future candidates for many therapeutic applications and can be the cure for many diseases such as neurodegenerative diseases, diabetes, and cancer [26]. Estrogen also influences the quality of life both in men and women and is a strong candidate in the maintenance of life standards. Estrogen has important effects on blood vessels, neurotransmitter release, sexual behaviour, bone structure, cognitive function and spermatogenesis and regulates many pathways vital for the homeostasis [27, 28]. Therefore our understanding of its importance should not be limited only to the reproductive system. In this study, we aimed to understand the role of estrogen on the MSCs which emerge as an important player of cellular-based therapies due to lack of immunogenicity and ethical problems.

Since we focused on the role of estrogen on MSCs, we first examined the expression status and functionality of ER $\alpha$ and ER $\beta$ on these cells (Fig. $1 b$ and c). Bone marrow is one of the target tissues of estrogen and osteoblasts,

A)

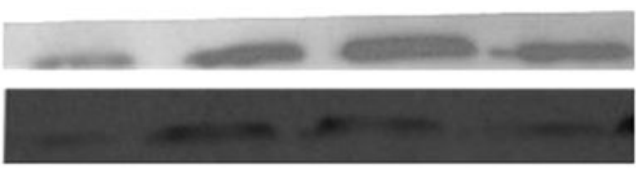

$\mathrm{BCl}-\mathrm{x}_{\mathrm{L}}$

Actin

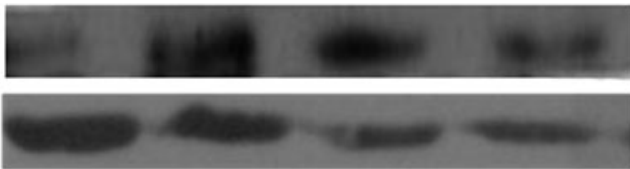

$\mathrm{Bcl}-2$

Actin

B)

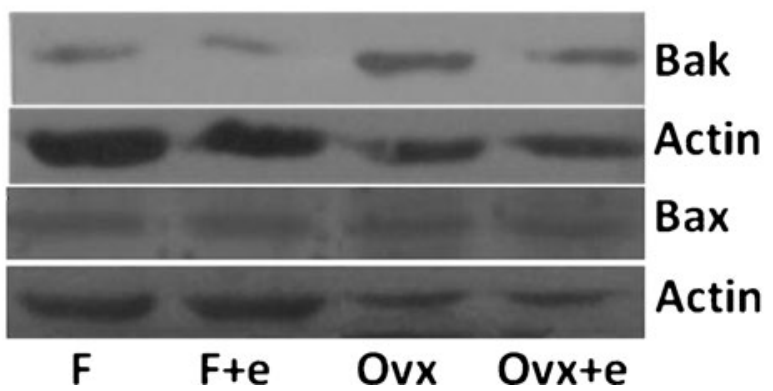

Fig. 4 Expression of $\mathbf{a}$ anti-apoptotic and $\mathbf{b}$ pro-apoptotic members of Bcl-2 family of proteins in MSCs determined by Western blot. Actin expression was used as loading control (F: MSCs obtained from female rats; $\mathrm{F}+\mathrm{e}$ : MSCs obtained from female rats treated with estrogen; Ovx: MSCs obtained from ovariectomized rats; Ovx $+\mathrm{e}$ : MSCs obtained from ovariectomized rats treated with estrogen) 
A)

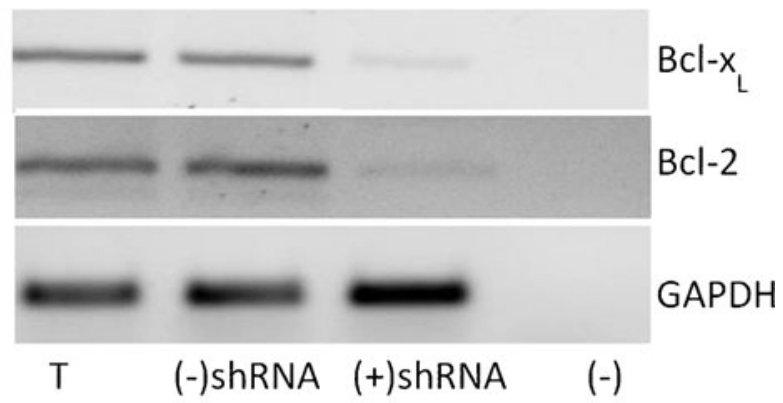

B) TUNEL Assay after Bcl-x knock down

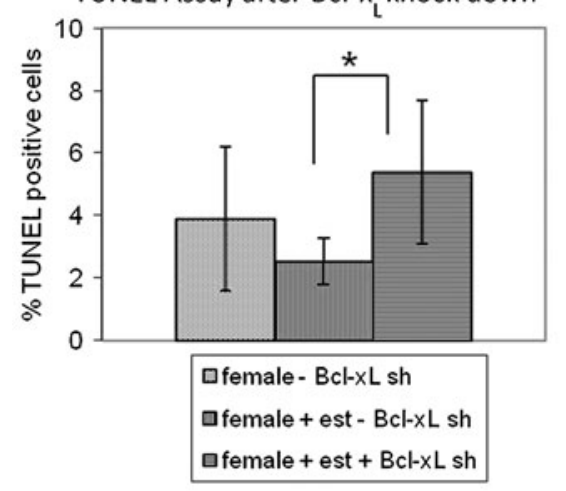

C) TUNEL Assay after Bcl-2 Knock down

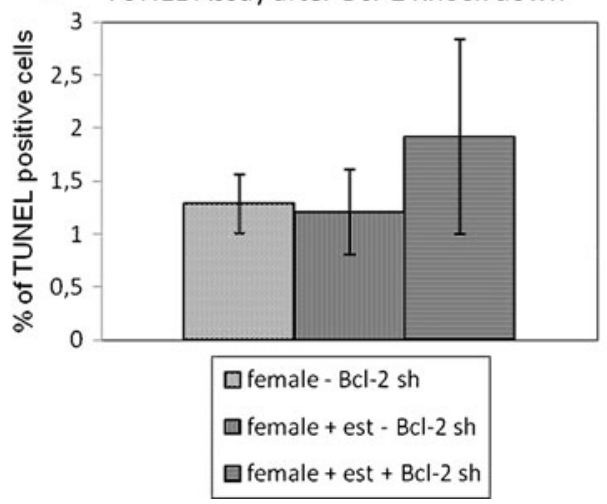

Fig. 5 Effect of silencing the expression of $b c l-x_{L}$ and $b c l-2$ on the apoptotic rates. a Expression of $b c l-2$ and $b c l-x_{L}$ determined by RTPCR in MSCs transfected with and without shRNA of $b c l-2$ and $b c l-$ $x_{L}$. T: control vector transfection. Expression of GAPDH was used as loading control. b Percentage of apoptotic cells after MSCs were transfected with $b c l-x_{L}$ shRNA determined by TUNEL assay. * indicates $p \leq 0.05$. c Percentage of apoptotic cells after MSCs were transfected with $b c l-2$ shRNA determined by TUNEL assay

osteocytes, osteoclasts, $\mathrm{T}$ cells and $\mathrm{B}$ cells in human and mouse bone marrow express both ER $\alpha$ and ER $\beta$ [29]. Our results showed that rat bone marrow-derived MSCs also express ER $\alpha$ and ER $\beta$ (Fig. 1b). Our data regarding to the expression of estrogen regulated gene, MMP12 [30], suggest that these receptors are functional. MSCs isolated both from normal and ovariectomized rats increased the expression of MMP12 upon estrogen addition (Fig. 1c).
Estrogen addition to the culture media increased the number of colonies both in the normal and ovariectomized group which suggests that estrogen has an increasing effect on the number of functional MSCs both in normal and estrogen deprived conditions (Fig. 2). In addition the number of cells in a colony was more when cells were treated with estrogen. These results are also in accordance with a previous study which showed that the number of MSCs obtained from ovariectomized animals was increased upon estrogen addition [31].

In addition, we observed that the differentiation potency of MSCs into adipocyte but not to osteocytes could be affected with estrogen. Estrogen has been shown to have an important role on adipocyte metabolism [32] and our results provided support that this effect might also be at the level of differentiation. It has been reported that MSCs from osteoporotic post-menopausal women showed an increase in PPAR $\gamma$ expression and thus an increase in adipocytes [33]. In addition, serum from post menopausal in comparison to serum from pre-menopausal women, were able to induce adipogenic differentiation in a human bone progenitor cell clone (hOP 7) derived from bone marrow [34]. Therefore, in the absence of estrogen, MSCs' adipocyte differentiation capacity increased suggesting that estrogen influences adipogenesis and this may explain why post-menopausal women gain weight and develop diseases associated with obesity. Molecular mechanism of this effect in MSCs is not known and clearly warranted new experiments.

The proliferative effect of estrogen has been shown on rat bone marrow-derived MSCs before [35]. In contrast to proliferation, the effect of estrogen on the maintenance of rat bone marrow-derived MSCs from normal animals have not been reported. We examined the effect of estrogen in the apoptotic rates of MSC by in situ cell death assay. When the ratios of apoptotic cells to total cells in the colonies were compared, the addition of estrogen decreased the death ratios in the normal and ovariectomized groups suggesting that estrogen is effective in the process of MSC colony formation both by decreasing apoptosis in addition to increasing proliferation. It is important to note that in our system, we did not induce apoptosis with any factor therefore we evaluated the spontaneous physiological apoptosis of bone marrow-derived MSCs.

In order to understand the molecular mechanism of the decrease in apoptosis upon estrogen administration, we focused on the Bcl-2 family of proteins. The Bcl-2 protein family consists of both pro- and anti-apoptotic members. The founder of the family, Bcl-2, was first identified in 1985 as the part of the most common translocation in human B-cell lymphoma [36]. After the identification of Bcl-2 as a survival factor, many different homologues were identified and characterized [37]. Recent reports established the effect of estrogen on the expression of Bcl-2 family of 
proteins in other systems $[19,23,24]$. Our immunoblotting and knock down data also suggested that estrogen controls the apoptosis by regulating the expression of $\mathrm{Bcl}-2$ family of proteins in rat MSCs (Fig. 4). These results are in correlation with other studies performed on other stem cells like skin stem cells, HSCs, and epithelial stem cells where apoptosis and members of the $b c l-2$ family of genes were shown to be important in the differentiation and regulatory pathways [38-40]. When we cultured MSCs in the presence of estrogen, the expression of anti-apoptotic Bcl-2 and Bcl$\mathrm{x}_{\mathrm{L}}$ were increased. This effect was more evident when MSCs were isolated from normal female rats than the ovariectomized rats. The Bcl-2 protein expression did not increase in the ovariectomized group, which might be explained by the loss of estrogen susceptibility due to a long period in an estrogen deprived environment. On the other hand, the expression of proapoptotic Bak and Bax proteins did not change with estrogen treatment. To confirm the role of anti-apoptotic Bcl-2 family of proteins on MSCs' maintenance, we silenced the expression of Bcl-2 and $\mathrm{Bcl}-\mathrm{x}_{\mathrm{L}}$. Our data showed that upon knocking down the expression of these genes, we observed the inhibition of apoptosis (Fig. 5) and CFU-F capacity of (data not shown) in MSCs isolated from normal and ovariectomized rats, suggesting a critical role for these genes in the estrogen regulation of apoptosis.

In conclusion, we have shown that apoptosis is one of the main regulatory mechanisms in the maintenance of MSCs. Bcl-2 and $\mathrm{Bcl}-\mathrm{x}_{\mathrm{L}}$ are important proteins in this regulation and estrogen affects the expression rates of these proteins, increasing the colonies and decreasing the apoptotic rate. Modulation of with estrogen may help to obtain more MSCs which might be important for clinical applications.

Acknowledgments This work was supported by the Scientific and Technological Research Council of Turkey grants SBAG105S393 to KCA

Conflict of Interest The authors declare no potential conflicts of interest

\section{References}

1. Friedenstein, A. J., Chailakhjan, R. K., \& Lalykina, K. S. (1970). The development of fibroblast colonies in monolayer cultures of guinea-pig bone marrow and spleen cells. Cell and Tissue Kinetics, 3, 393-403.

2. da Silva Meirelles, L., Caplan, A. I., \& Nardi, N. B. (2008). In search of the in vivo identity of mesenchymal stem cells. Stem Cells, 26, 2287-2299.

3. Tokcaer-Keskin, Z., Akar, A. R., Ayaloglu-Butun, F., et al. (2009). Timing of induction of cardiomyocyte differentiation for in vitro cultured mesenchymal stem cells: a perspective for emergencies. Canadian Journal of Physiology and Pharmacology, 87, 143-150.

4. Karp, J. M., \& Leng Teo, G. S. (2009). Mesenchymal stem cell homing: the devil is in the details. Cell Stem Cell, 4, 206-216.

5. Zipori, D. (2006). The mesenchyme in cancer therapy as a target tumor component, effector cell modality and cytokine expression vehicle. Cancer Metastasis Reviews, 25, 459-467.

6. Sasaki, M., Abe, R., Fujita, Y., Ando, S., Inokuma, D., \& Shimizu, H. (2008). Mesenchymal stem cells are recruited into wounded skin and contribute to wound repair by transdifferentiation into multiple skin cell type. Journal of Immunology, 180, 2581-2587.

7. Phinney, D. G., \& Prockop, D. J. (2007). Concise review: mesenchymal stem/multipotent stromal cells: the state of transdifferentiation and modes of tissue repair-current views. Stem Cells, 25, 2896-2902.

8. Pittenger, M. F., Mackay, A. M., Beck, S. C., et al. (1999). Multilineage potential of adult human mesenchymal stem cells. Science, 284, 143-147.

9. Santen, R. J., \& Allred, D. C. (2007). The estrogen paradox. Nature Clinical Practice. Endocrinology \& Metabolism, 3, 496497.

10. Maximov, P. Y., Lewis-Wambi, J. S., \& Jordan, V. C. (2009). The paradox of oestradiol-induced breast cancer cell growth and apoptosis. Current Signal Transduction Therapy, 4, 88-102.

11. Clarke, B. L., \& Khosla, S. (2010). Female reproductive system and bone. Archives of Biochemistry and Biophysics, 503, 118-128.

12. Skafar, D. F., Xu, R., Morales, J., Ram, J., \& Sowers, J. R. (1997). Clinical review 91: female sex hormones and cardiovascular disease in women. Journal of Clinical Endocrinology and Metabolism, 82, 3913-3918.

13. Hughes, D. E., Dai, A., Tiffee, J. C., Li, H. H., Mundy, G. R., \& Boyce, B. F. (1996). Estrogen promotes apoptosis of murine osteoclasts mediated by TGF- $\beta$. Nature Medicine, 2, 1132-1136.

14. Kameda, T., Mano, H., Yuasa, T., et al. (1997). Estrogen inhibits bone resorption by directly inducing apoptosis of the bone-resorbing osteoclasts. The Journal of Experimental Medicine, 186, 489-495.

15. Okasha, S. A., Ryu, S., Do, Y., McKallip, R. J., Nagarkatti, M., \& Nagarkatti, P. S. (2001). Evidence for estradiol-induced apoptosis and dysregulated T cell maturation in the thymus. Toxicology, 163, 49-62.

16. Nilsen, J., Mor, G., \& Naftolin, F. (2000). Estrogen-regulated developmental neuronal apoptosis is determined by estrogen receptor subtype and the Fas/Fas ligand system. Journal of Neurobiology, 43, 64-78.

17. Tomkinson, A., Gevers, E. F., Wit, J. M., Reeve, J., \& Noble, B. S. (1998). The role of estrogen in the control of rat osteocyte apoptosis. Journal of Bone and Mineral Research, 13, 1243-1250.

18. Spyridopoulos, I., Sullivan, A. B., Kearney, M., Isner, J. M., \& Losordo, D. W. (1997). Estrogen-receptor-mediated inhibition of human endothelial cell apoptosis. Estradiol as a survival factor. Circulation, 95, 1505-1514.

19. Pike, C. J. (1999). Estrogen modulates neuronal Bcl- $x_{L}$ expression and beta-amyloid-induced apoptosis: relevance to Alzheimer's disease. Journal of Neurochemistry, 72, 1552-1563.

20. Gompel, A., Somai, S., Chaouat, M., et al. (2000). Hormonal regulation of apoptosis in breast cells and tissues. Steroids, 65, 593-598.

21. Martinou, J. C., \& Green, D. R. (2001). Breaking the mitochondrial barrier. Nature Reviews. Molecular Cell Biology, 2, 63-67.

22. Zamzami, N., \& Kroemer, G. (2001). The mitochondrion in apoptosis: how Pandora's box opens. Nature Reviews. Molecular Cell Biology, 2, 67-71.

23. Perillo, B., Sasso, A., Abbondanza, C., \& Palumbo, G. (2000). 17beta-estradiol inhibits apoptosis in MCF-7 cells, inducing bcl-2 expression via two estrogen-responsive elements present in the coding sequence. Molecular and Cellular Biology, 20, 2890-2901. 
24. Yune, T. Y., Park, H. G., Lee, J. Y., \& Oh, T. H. (2008). Estrogeninduced Bcl-2 expression after spinal cord injury is mediated through phosphoinositide-3-kinase/Akt-dependent CREB activation. Journal of Neurotrauma, 25, 1121-1131.

25. Bradford, M. M. (1976). A rapid and sensitive method for the quantitation of microgram quantities of protein utilizing the principle of protein-dye binding. Analytical Biochemistry, 72, 248-254.

26. Fuchs, E., \& Segre, J. A. (2000). Stem cells: a new lease on life. Cell, 100, 143-155.

27. Simpson, E. R. (2003). Sources of estrogen and their importance. The Journal of Steroid Biochemistry and Molecular Biology, 86 (3-5), 225-230.

28. Simpson, E., Rubin, G., Clyne, C., Robertson, K., O’Donnell, L., Davis, S., et al. (1999). Local estrogen biosynthesis in males and females. Endocrine-Related Cancer, 6(2), 131-137.

29. Weitzmann, M. N., \& Pacifici, R. (2006). Estrogen deficiency and bone loss: an inflammatory tale. The Journal of Clinical Investigation, 116, 1186-1194.

30. Tee, M. K., Rogatsky, I., Tzagarakis-Foster, C., et al. (2004). Estradiol and selective estrogen receptor modulators differentially regulate target genes with estrogen receptors $\alpha$ and $\beta$. Molecular Biology of the Cell, 15, 1262-1272.

31. Zhou, S., Zilberman, Y., Wassermann, K., Bain, S. D., Sadovsky, Y., \& Gazit, D. (2001). Estrogen modulates estrogen receptor alpha and beta expression, osteogenic activity, and apoptosis in mesenchymal stem cells (MSCs) of osteoporotic mice. Journal of Cellular Biochemistry. Supplement, 36, 144-155.

32. Mattsson, C., \& Olsson, T. (2007). Estrogens and glucocorticoid hormones in adipose tissue metabolism. Current Medicinal Chemistry, 14, 2918-2924.
33. Rodriguez, J. P., Astudillo, P., Rios, S., \& Pino, A. M. (2008). Involvement of adipogenic potential of human bone marrow mesenchymal stem cells (MSCs)in osteoporosis. Current Stem Cell Research \& Therapy, 3, 208-218.

34. Stringer, B., Waddington, R., Houghton, A., Stone, M., Russell, G., \& Foster, G. (2007). Serum from postmenopausal women directs differentiation of human clonal osteoprogenitor cells from an osteoblastic toward anadipocytic phenotype. Calcified Tissue International, 80, 233-243.

35. Hong, L., Sultana, H., Paulius, K., \& Zhang, G. (2009). Steroid regulation of proliferation and osteogenic differentiation of bone marrow stromal cells: a gender difference. The Journal of Steroid Biochemistry and Molecular Biology, 114, 180-185.

36. Bakhshi, A., Jensen, J. P., Goldman, P., et al. (1985). Cloning the chromosomal breakpoint of $\mathrm{t}(14 ; 18)$ human lymphomas: clustering around $\mathrm{JH}$ on chromosome 14 and near a transcriptional unit on 18. Cell, 41, 899-906.

37. Tsujimoto, Y., \& Shimizu, S. (2000). Bcl-2 family: life-or-death switch. FEBS Letters, 466, 6-10.

38. Potten, C. S., Wilson, J. W., \& Booth, C. (1997). Regulation and significance of apoptosis in the stem cells of the gastrointestinal epithelium. Stem Cells, 15, 82-93.

39. Polakowska, R. R., Piacentini, M., Bartlett, R., Goldsmith, L. A., \& Haake, A. R. (1994). Apoptosis in human skin development: morphogenesis, periderm, and stem cells. Developmental Dynamics, 199, 176-188.

40. Domen, J., Cheshier, S. H., \& Weissman, I. L. (2000). The role of apoptosis in the regulation of hematopoietic stem cells: Overexpression of Bcl-2 increases both their number and repopulation potential. The Journal of Experimental Medicine, 191, 253-264. 